\section{A TREATISE ON SPINES.}

A SERIES of papers upon "The Origin and Significance of Spines: a Study in Evolution," contributed by Dr. C. E. Beecher to the American Journal of Science from July to October last, has now been distributed by their author in a collected form. There are 80 pages in all, with 73 text illustrations, tables, and a plate delineating leading types of Radiolarian spines after Haeckel. Under the head of "spines" there are dealt with objects between and including "the modified hairs of the Echidna and Porcupine," and "the projecting rays and processes of Radiolaria "; movable and fixed forms are alike passed in review, horns and antlers come in for consideration, and only such "spines" appear to be disregarded as are "distinctly internal structures."

The author has been at immense pains to bring together all that is known concerning the nature, origin, laws of growth and limitations of spines, not excluding those met with in the vegetable kingdom; and while, in arranging in an orderly manner this vast accumulation of facts, he has done a good service, we venture to think that the utility of his essay is, to a large extent, marred by the too sudden diversion into side topics which at times appear to us irrelevant. The "law of variation," according to Cope ; that of "multiplication of effects," according to Herbert Spencer ; the principle of " localised stages of growth," by Jackson ; of " reproductive divergence," by Vernon; with "sexual selection," and other supposed laws and heresies, are all in turn called in for comment and consideration. The author so flits about among extremes concerning both organs and doctrines under review, that the reader is often at a loss to discover his views and arguments, and at what he is sometimes aiming. Of all his theses, that which he seems to us to have best substantiated is expressed in his concluding remark that "after attaining the limit of spine differentiation spinose organisms leave no descendants, and .... that out of spinose types no new types are developed." The subject of "spines" is a notoriously fascinating one upon which much has been written. On perusal of the excellent list of references which accompanies the papers, and comparison with the text, the author appears to us to have exercised too little discrimination in his reading, and to have been too prone to accept much which he found in print. Some of his allusions to the fishes and the desert plants appear especially open to this objection. His reputation is now so well established among working zoologists, in connection with his recent magnificent investigations into the phylogeny of the Brachiopoda and the structure and systematic position of the Trilobites-achievements of which even Yale College Museum may well be proud-that his present series of papers will be widely read. While we are profoundly thankful to him for having collected together and arranged in a workable form so instructive an amount of detail, we doubt if some of his conclusions will prove any more convincing to the majority than those which three years ago led him to a belief in the so-called Protaspis larva.

\section{FOSSIL JELLY-FISH.}

$A^{N}$ elaborate work on Fossil Medusæ, by Mr. C. D. Walcott, forms the thirtieth volume of the Monographs of the United States Geological Survey. The attention of the author was first directed to the occurrence of certain siliceous nodules, known as "star-cobbles," in the Middle Cambrian shales of Alabama; and after coming to the conclusion that these nodules contained fossil Meduse, he was led to extend his researches to all the known fossil forms. Among these some had been recognised in Sweden by Nathorst, and in Bavaria by Haeckel ; and the full record embraces forms from the Cambrian of the United States, Sweden, Russia, and Bohemia ; from the Permian of Saxony; and from the Jurassic of Bavaria.

The author points out that, under certain conditions, when a Medusa is overwhelmed by muddy sediment, it may retain its shape sufficiently long for the sediment to solidify and make a mould of its external form. Plaster-casts of certain jelly-fish may in some instances be readily obtained. The most favourable conditions for the natural preservation of a Medusa appear to be by burial and rapid consolidation of sediment beneath water but the author observes that not one in a hundred of the fossi specimens, shows traces of any structure within the hndy, and, so far as is known, the particularly favourable conditions required " were confined during geologic time to the vicinity of the spot in the Cambrian sea that is now occupied by the township of Cedar Bluff, Cherokee County, Alabama." There the nodules with Medusæ occur in finely laminated shales, and much of the silica forming the nodules appears to be original, and derived from the solution of siliceous organisms. The Medusæ lived in relatively shallow water, and were quickly overwhelmed and buried in a siliceous mud that was subsequently consolidated to form a siliceous shale. The silica which forms a large portion of the shale, was probably derived from detrital quartz.

The author discusses the relation of the Medusæ to the Sponges, and more especially of the Middle Cambrian forms ; and he then proceeds to describe the various species, which are illustrated in forty-seven plates. These figures will prove of considerable interest to geologists; they serve to draw attention to many curious and hitherto problematical structures ; and may lead to more precise information with regard to their mode of occurrence. There appears to be no doubt that some of the forms, even of Cambrian age, are true Medusæ; and the author believes that at this early period, if not in pre-Cambrian times, the acraspedote Medusæ were mainly differentiated. He remarks, however, that we have yet much to learn about the medusiform ancestors of the Hydrozoa.

\section{SEASONAL DIMORPHISM IN LEPIDOPTERA.1}

I HAVE thought this to be a suitable subject for my address, because it is not only of high interest as a remarkable phase of variation, but has also of late years been brought prominently to notice by the researches of two groups of entomological observers ; firstly, those who, like the pioneers, G. Dorfmeister, W. H. Edwards and August Weismann, have experimentally studied the effects of high and low temperatures artificially applied to lepidopterous pupæ of European or North American species; and secondly, those who have noted the seasonal changes in butterflies occurring naturally in various tropical and subtropical regions, and have in some cases reared one seasonal form of a species from ova deposited by the other. The earlier temperature experiments in Europe and North America were long in advance of the observations on seasonal dimorphism in tropical countries, the latter indeed being the natural outcome of the former. It may prove not uninteresting if I briefiy pass under review the published memoirs relating to both sets of observations, but, as regards the temperature experiments, limiting my remarks almost exclusively to those relating to seasonally-dimorphic species.

No doubt many of us remember with what interest we welcomed Weismann's able treatise ${ }^{2}$ published twenty-three years ago, whether in the original or in the English edition (translated by Prof. Meldola) issued in 1882 . The cases known to Weismann, and described in this memoir, were not numerous; he calls special attention to six European cases (Araschnia levana, Lycaena amyntas, L. agestis, Chrysophanus phlaeas, Pieris napi, and Euchloe belia), and to three North American (Phyciodes tharos, Grapta interrogationis and Papilio. ajax), the latter known to science through the investigations of W. H. Edwards, the well-known monographer of the butterflies of North America, whose experiments and results ${ }^{3}$ are republished with additions as Appendix II. to Weismann's essay. In the phenomenon of seasonal dimorphism Weismann recognised, as two prominent factors in the possible direct influence of the varying external conditions of life, temperature and duration of the pupal period; and his experiments with Araschnia levana and Pieris napi were accordingly carried on with the view of ascertaining whether the dimorphism exhibited by those species could be traced to the direct action of those factors. In the case of $A$. levana, he first subjected the pupx obtained from eggs laid by the winter form, immediately after pupation, to artificial low temperatures, and the result was that, by exposure to temperature of $0^{\circ}-I^{\circ} \mathrm{R}$. for four weeks, three-

1 An address read before the Entomological Society of London at the annual meeting on January 18, by Roland Trimen, F.R.S., President of the Society.

2 "Studien zur Descendenz-Theorie. I. Ueber den Saison-Dimorphismus der Schmetterlinge," 1875.

3 Canadian Entomologist, vii. p. 236 (1875), and ix. p. 69 (1879).

NO. I 537, vOL. 59] 